\title{
A Guide to Educating Different Generations in South Africa
}

\author{
Kevin Johnston \\ University of Cape Town, Cape Town, South Africa
}

kevin.johnston@uct.ac.za

\begin{abstract}
The majority of academics teaching Information Systems today were born somewhere between 1943 and 1981 (Baby Boomers or Generation X), while the majority of students were born after 1982 (Net Generation or iGeneration). One generation is always tasked with educating another generation, which has different likes and dislikes. This paper reviews papers written on educating the two different generations in South Africa, what academics (Baby Boomers and Generation X) need to know to better educate students (Net Generation and iGeneration).

Six South African papers on learning preferences, and use of Information and Communication Technology (ICT) were reviewed. Over 1500 university students in 7 South African Universities, plus 122 IS academics were involved. Gaps in perceptions and usage were identified between generations, and recommendations made as how to treat the gaps to better facilitate the education of the Net and iGenerations.

Vodcasting (video on demand) was introduced to a first year class of 605 students in 2011 at the University of Cape Town, South Africa as a learning supplement. At the end of the course, students were surveyed on amongst other issues, the benefits of vodcasting.

The study revealed that the students favoured the use of interactive, practical and visual learning styles. The academics underestimated the students' affinity for interactive and online learning, and failed to grasp the effects of the use of mobile phones and social networking on students learning styles.
\end{abstract}

Keywords: Learning Preferences, Learning Styles, Technological Expectations, Net-generation, iGeneration, Tertiary Education, South Africa.

\section{Introduction}

Generations are bands of time which include the birth years of individuals that share similar characteristics as shaped by the events and circumstances surrounding their lives (Howe \& Strauss, 2007). Although people of the same generation tend to hold similar perceptions and beliefs, no

Material published as part of this publication, either on-line or in print, is copyrighted by the Informing Science Institute. Permission to make digital or paper copy of part or all of these works for personal or classroom use is granted without fee provided that the copies are not made or distributed for profit or commercial advantage AND that copies 1) bear this notice in full and 2) give the full citation on the first page. It is permissible to abstract these works so long as credit is given. To copy in all other cases or to republish or to post on a server or to redistribute to lists requires specific permission and payment of a fee. Contact Publisher@InformingScience.org to request redistribution permission. person completely fits the profile of any particular generation (Rosen, 2011). There are several identified sets of generations: the Matures born between 1900 and 1942, the Baby Boom generation born 1943 and 1960, Generation X born between 1961 and 1981, the Net Generation born between 1982 and 1991, and the iGeneration born after 1991 . Table 1 tabulates some differences in the generations. Earlier generations are 
now the parents, teachers, co-workers, superiors or mentors of later generations. Earlier generations attempt to shape later generations (Howe \& Strauss, 2007). However, a strong influence on the Net and iGenerations has been computer technology and the internet, and their adoption in the home, at schools and at work (Oblinger \& Oblinger, 2005; Rosen, 2011; Waldron, 2012). The Net and iGenerations have "grown up with technology," and have an "information-age mindset" which believes that the computer is not a technology but an assumed part of life, they spend more time online than watching TV (Oblinger \& Oblinger, 2005; Howe \& Strauss, 2007; Rosen, 2011; Waldron, 2012). Due to their exposure to technology, the Net and iGeneration have a low tolerance to delays, and want information at their fingertips. Net Generation people are activists, preferring to try things out themselves in a trial-and-error approach rather than knowing. They favour activity and application to abstract logic (Frand, 2000; Brown, 2000) and have adopted the "learning by doing" culture (Oblinger, 2003), they have embraced social networks software (eg Facebook and Twitter) and instant messaging (Waldron, 2012). The iGeneration "so called because of their use of the iPhone, iPod, iPad (and iEverything), who have redefined communication not only by their acceptance of and hunger for new devices, but because of their sometimes overwhelming reliance on technology for being in touch with others and interpreting their world" (Waldron, 2012, 2-3).

People of the Net and iGenerations have a strong desire to stay connected to others, and use a variety of devices to do so. Penmanship has been superseded by keyboarding skills, and typing rather than handwriting is valued (Frand, 2000). These favoured approaches and learning styles however, bring with them new challenges in the education arena, especially to those providing the education - the teachers. The teachers from prior generations have to restructure their traditional teaching methods to suit the later generation's new and technological enhanced methods of learning (Kapp, 2007).

\section{Table 1: Summary of the characteristics of each generation (Oblinger \& Oblinger, 2005; Howe} \& Strauss, 2007; Rosen, 2011; Waldron, 2012).

\begin{tabular}{|l|l|l|l|l|l|}
\hline & MATURES & $\begin{array}{l}\text { BABY BOOM- } \\
\text { ERS }\end{array}$ & $\begin{array}{l}\text { GENERA- } \\
\text { TION X }\end{array}$ & $\begin{array}{l}\text { NET GENER- } \\
\text { ATION }\end{array}$ & IGENERATION \\
\hline Birth Dates & $1900-1942$ & $1943-1960$ & $1961-1981$ & $1982-1991$ & $1992-$ \\
\hline Description & $\begin{array}{l}\text { Greatest gen- } \\
\text { eration }\end{array}$ & Me generation & $\begin{array}{l}\text { Latchkey gen- } \\
\text { eration }\end{array}$ & Millennials & $\begin{array}{l}\text { Plurals - no majority } \\
\text { race, dominant me- } \\
\text { dia, or family unit }\end{array}$ \\
\hline Attributes & $\begin{array}{l}\text { Command and } \\
\text { control } \\
\text { Self-sacrifice }\end{array}$ & $\begin{array}{l}\text { Optimistic } \\
\text { Workaholic }\end{array}$ & $\begin{array}{l}\text { Independent } \\
\text { Sceptical }\end{array}$ & $\begin{array}{l}\text { Hopeful } \\
\text { Determined }\end{array}$ & $\begin{array}{l}\text { High expectations, } \\
\text { items tailored to } \\
\text { wants \&needs }\end{array}$ \\
\hline $\begin{array}{l}\text { Respect for: } \\
\text { Authority }\end{array}$ & $\begin{array}{l}\text { Responsibility } \\
\text { Womily }\end{array}$ & $\begin{array}{l}\text { Freedom } \\
\text { Multitasking } \\
\text { Community }\end{array}$ & $\begin{array}{l}\text { Can-do attitude } \\
\text { Work-life bal- } \\
\text { ance }\end{array}$ & $\begin{array}{l}\text { Latest tech- } \\
\text { nology } \\
\text { Parents }\end{array}$ & $\begin{array}{l}\text { Mublic activ- } \\
\text { social worlds, brands } \\
\text { advertising }\end{array}$ \\
\hline Dislikes & $\begin{array}{l}\text { Waste } \\
\text { Technology }\end{array}$ & $\begin{array}{l}\text { Laziness } \\
\text { Turning } 50\end{array}$ & $\begin{array}{l}\text { Red tape } \\
\text { Hype }\end{array}$ & $\begin{array}{l}\text { Anything slow } \\
\text { Negativity }\end{array}$ & $\begin{array}{l}\text { Failure, and unhap- } \\
\text { piness }\end{array}$ \\
\hline
\end{tabular}

In the developed economies, educationalists have restructured and transformed their learning styles to ensure that the next generations are provided with an educational experience that is meaningful and more appropriate (Frand 2000). However, in a developing country such as South 
Africa where technological infrastructure is not yet mature and technological resources such as computers and Internet are not readily accessible, restructuring and transforming the educational experience of the Net and iGeneration is a challenge. This study therefore, investigates how the Net and iGenerations of South Africa prefer to learn, and how the academics of previous generations perceive the learning preferences of the Net and iGenerations.

Three changes in higher education which received attention in literature on universities over the past 10-15 years have been massification, managerialism, and Information and Communication Technology. Massification is the growth in student (and staff) numbers at universities. Only a small percentage of the global population attended university before the end of WWII (Rinne, 2009; Wallerstein, 2004). UNESCO figures show the number of tertiary higher education students increased globally from 51,160,000 in 1980 to 139,395,000 in 2006 (Rinne, 2009). Universities thus had to manage larger and more diverse student bodies (Boughey, 2009), whilst budgets started decreasing from the late 1980's (Rinne, 2009).

Managerialism is a term generally used to describe how universities have adopted a managerial approach to the running of their operations (Hayes \& Utecht, 2009; Mowles, Stacey, \& Griffin, 2008). Managerial approaches such as strategic planning, management by objectives, performance appraisals, decentralised budgeting, fewer levels of decision-making, flatter administrative structures, executive dashboards, and outsourcing have been introduced into universities (Barnett, 2005; du Toit, 2000; Rinne, 2009). As a result, universities have seen an increasing emphasis on accountability, performance management, productivity, commitment, risk management, quality assurance, and professional standards (Baird, 2010; Grummell, Devine, \& Lynch, 2009; Ntshoe, Higgs, Higgs, \& Wolhute, 2008). Managerialism changed universities from 'communities of scholars' into 'workplaces', and many academics feel that universities have lost their unique culture (Deem, Hillyard, \& Reed, 2007).

Massification and managerialism have led to an increased reliance on information and communication technology (ICT), and an increased need for university staff to learn and use ICT for both teaching and administration (Brewer \& Walker, 2010; Moratis \& van Baalen, 2002; Ntshoe, Higgs, Higgs, \& Wolhute, 2008). Until recently, the principal impact of ICT in universities has been in administration and in libraries (Coaldrake \& Stedman, 1999). However, ICT is having a significant impact on higher education and its potential for innovation in teaching and learning has been enhanced by the growing power of networked computing and the convergence of information and communication technology (Coaldrake \& Stedman, 1999; Johnston, 2010). The advent of computer technology and the proliferation of its applications in education have resulted in changes to how students are taught, and how they learn. Until the late 1980's university classes were small and almost no technology was used to teach or to learn (Rinne, 2009). Students took classes and tutorials, visited the library, read papers and made notes to learn, the only technology used was a photocopier. Communication with academics was generally face to face; telephones were seldom if ever used.

\section{Methodology}

The underlying philosophy of the study is interpretive. A qualitative thematic analysis was conducted through the analysis of peer reviewed academic literature and unpublished university research from South Africa. Most of the data is not primary, as it is from the works of other authors and so has been subjected to relative and subjective scrutiny of the authors and reviewers (Walsham, 1995).

A qualitative analysis was conducted of the literature to assess and explore the state of educating different generations in South Africa. The search process followed a systematic approach as de- 
fined by Hauge, Ayala and Conradi (2010). Digital libraries formed the primary basis from which the search process was conducted.

To avoid overlooking relevant publications the search strategy that was adopted was one of high sensitivity using various keywords (Hauge et al., 2010). This process yielded 23 articles that were then reviewed based on their abstracts and titles. Only papers that referred to the themes identified were considered, this yielded the following 6 main papers that were used in the study.

- $\quad$ Addo and Railton (2008) surveyed 307 students and 15 IS academics across three South African universities. The survey assessed the impact of ICT on learning for the students and academics at the Cape Peninsula University of Technology (CPUT), the University of Cape Town (UCT), and the University of the Witwatersrand (Wits). Two questionnaires were used, one for students and one for academics. Students surveyed ranged in year of study and in degree choice. Of the CPUT students, 50\% were in 2nd year of study and 49\% in 3rd year, with 54\% majoring in Business and $43 \%$ in IT. The UCT cohort consisted of $82 \%$ in 1 st year, $6 \%$ in 2 nd year, and $6 \%$ in post graduate study, with $82 \%$ majoring in business and $12 \%$ in IT. The Wits cohort consisted of $40 \%$ in 1 st year, $34 \%$ in 2 nd year and $26 \%$ doing post graduate studies, with $45 \%$ majoring in business, $33 \%$ in IT, and 15\% in Engineering.

- Johnston, Kawalsky, Lalla and Tanner (2011) surveyed 572 randomly selected students from seven South African universities on the benefits of Facebook. The universities surveyed included CPUT, UCT, Wits, plus Fort Hare, Stellenbosch University, the University of Johannesburg (UJ), and the University of the Western Cape (UWC). No detailed demographics of the students were provided in the paper.

- Ng'ambi, Lombe, Johnston, and Kabanda (2010) followed an Action Research approach using an ethnographic method at UCT. Podcasting was introduced into a class of 411 first year B.Com students, the majority majoring in Accounting and Business at the University of Cape Town.

- $\quad$ Roodt, de Villiers, Johnston, Ophoff and Peier (2012) surveyed 15 IS academics from five South African Universities on their use of YouTube as an academic tool. Academics from Rhodes University, UCT, UJ, University of Pretoria, and University of Zululand were surveyed.

- $\quad$ Samsodien (2012) surveyed 298 first year B.Com UCT students, the majority majoring in Accounting and Business on their use of mobile phones.

- Visagie and de Villiers (2010) surveyed 86 IS Academics from 5 countries (Australia, Canada, South Africa, United Kingdom, and the United States) on the use of Facebook as an academic tool.

Four of the six papers were peer-reviewed through conferences or journals, the Addo and Railton (2008) and Samsodien (2012) papers are unpublished post graduate research papers.

South Africa has 23 public universities, some old and established such as UCT (founded in 1829), Fort Hare (1916), Wits (1922), UP (1930), while other are the result of recent amalgamations of several higher educational institutions such as CPUT and UJ which were founded in 2005. In terms of student numbers, the largest are UJ and UP with about 50,000 each and CPUT with 32,000, Wits and UCT have about 28,000 students, while UWC has 12,000 and Rhodes has 6,000 . UCT host more than $25 \%$ of South Africa's A-rated researchers, and is the highest ranked university in Africa.

Following on the research done by Ng'ambi, Lombe, Johnston, and Kabanda in 2010, vodcasting was implemented as a learning supplement in the teaching of two large classes over 2011 and 2012. Online survey questionnaires were used to collect data on the impact of the change. Survey questionnaires are considered to be one of the most widely used data collection techniques within 
the survey strategy (Saunders, Lewis \& Thornhill, 2009). The survey questionnaire was created on the Learning Management System (LMS) used by the institute. The survey was available to respondents for a period of 2 weeks. The results from the survey were captured and normalised into spread sheets in Microsoft Excel for analysis. The surveys allowed the researcher to collect quantitative data which was analysed using descriptive and inferential statistics (Saunders, Lewis \& Thornhill, 2009).

\section{Analysis of Literature}

The advancement of ICT and its proliferation amongst students has brought about new leaning preferences. These preferences are: interactive, online, practical, and visual. The interactive learning preference is a process of acquiring knowledge through the interaction between people in the learning environment. The Net and iGeneration have a high need for engagement and immediacy (Ramaley \& Zia, 2005; Oblinger and Oblinger, 2005), and the internet and related tools facilitate interactive learning (Hartman et al., 2005). The Net and iGeneration's satisfaction with the internet and web-based media makes online learning the preferred approach (Oblinger \& Oblinger, 2005). Students' primary sources of information for coursework tended to be Web based, and search engines such as Google were the first place to garner information rather than using the library (Lippincott, 2005). This has raised concerns as students are unable to adequately evaluate the quality of sources found on the Web, and has resulted in efforts to make academic content available on the Web through services such as Google Scholar (Lippincott, 2005).

The interactive learning preference emphasises the importance of providing relevant material to which learners can apply the concepts they have learned. It also focuses on the doing, rather than knowing approach. An example is the use of case studies to apply theory to real situations, as the Net and iGenerations have a strong need for relevance (McNeely, 2005; Windham, 2005). In addition to practically, the Net and iGenerations possess a quality of being able to read and interpret information presented visually. They have a sense of visual-spatial skills and thus are more visually literate than their predecessors (Oblinger \& Oblinger, 2005; Kapp, 2007), and prefer the use of multimedia to enhance the learning experience (Clayton-Pedersen \& O'Neill, 2005).

The Net and iGeneration are more empowered with information, and no longer strictly rely on an expert or go to the library but instead use the web to find information (Lorenzo \& Dziuban, 2006). Although they view the educationalist as vital to their learning success, they still have high expectations of faculty member's technology expertise and usage of technology in a classroom (Oblinger \& Oblinger, 2005). Even though they seem to have high preferences and aptitudes for technology as well as an expressed desire for its use in the learning environment, they "care about the activity technology enables, not the technology, per se" (Wager, 2005, p. 10.4). Their interest is on how technology can assist them in their assignment. This has raised concerns amongst academics, especially "about information gathering, technology use, and critical thinking approaches" (Lorenzo \& Dziuban, 2006).

Addo and Railton (2008) surveyed 307 students and 15 IS academics as to their learning preferences ( 1 being the least preferred and 5, the most preferred). The findings are depicted in Table 2, and show some significant difference between student and academics. Students preferred attending a class or a practical demonstration, followed by the "friend to show me how" learning preference. Academics however favoured the "Just do it and See What Works" approach usually achieved through workshops or tutorials. The least favoured learning preference for both samples was the "read an online instruction manual". 


\begin{tabular}{|l|l|l|l|l|}
\hline \multicolumn{4}{|c|}{ Table 2: Summary of learning preferences (Addo \& Railton, 2008). } \\
\hline \multirow{2}{*}{ LEARNING PREFERENCES } & \multicolumn{2}{|c|}{ STUDENTS } & \multicolumn{2}{c|}{ ACADEMICS } \\
\cline { 2 - 5 } & Mean & St. Dev & Mean & St. Dev \\
\hline Take a class or attend a demonstration & 4.10 & 1.01 & 3.20 & 1.21 \\
\hline Have a friend show me & 3.41 & 1.10 & 2.93 & 1.39 \\
\hline Just do it and see what works & 3.07 & 1.33 & 4.07 & 1.21 \\
\hline Read a paper instruction manual & 3.01 & 1.24 & 3.27 & 1.22 \\
\hline Read an online instruction manual & 2.73 & 1.09 & 2.87 & 1.36 \\
\hline
\end{tabular}

The Interactive learning style was found to be the most favoured by both students and the academics, who confirmed statements such as "interacting with fellow students in class improves student learning" and "in order to learn best, students need face-to-face contact with an instructor" (Addo \& Railton, 2008). In addition, students believed that the use of online discussion boards and forums were useful to their learning. Students abhorred learning independently and not working with others, academics perceived that students felt less inclined towards this solitary nature of learning (Addo \& Railton, 2008). Students valued the presence of an academic higher than resources on the internet, albeit slightly, which is in line with other studies (Oblinger \& Oblinger, 2005). A consensus on the visual learning style was also reached between the two samples as they both agreed that "Students learn best when there is a variety of visual material presented in class" (Addo \& Railton, 2008). Students tended to strongly favour a practical learning style (Addo \& Railton, 2008), which matches studies conducted on students from the Net Generation in the USA (Windham, 2005).

Students expect academics to use technology (particularly presentation software, course management systems, and email) whilst conducting a class (Addo \& Railton, 2008), as can be seen in Table 3. Students were asked to rate their expectations of academics with regards to the use of the technologies outlined in table 3 on a four point scale ranging from 4 which was fully expected use, to 1 which was not wanted. Academics were asked to rate their use of the technologies on the same 4 point scale.

\begin{tabular}{|c|c|c|c|c|}
\hline \multirow[t]{2}{*}{ TECHNOLOGY } & \multicolumn{2}{|c|}{ STUDENTS EXPECTATIONS } & \multicolumn{2}{|c|}{ ACADEMICS USE } \\
\hline & Mean & St. Dev & Mean & St. Dev \\
\hline Presentation software in class & 3.47 & 0.66 & 3.73 & 0.46 \\
\hline A course management system & 3.37 & 0.73 & 3.57 & 0.65 \\
\hline Communication with students via email & 3.06 & 0.91 & 3.53 & 0.92 \\
\hline Course discussion boards & 2.99 & 0.82 & 3.43 & 0.76 \\
\hline Delivery of most course content online & 2.79 & 1.05 & 3.00 & 1.20 \\
\hline Internet in class & 2.65 & 0.78 & 2.80 & 0.86 \\
\hline Online chat & 2.36 & 0.86 & 2.14 & 1.29 \\
\hline Instant Messaging & 2.28 & 0.95 & 2.21 & 1.37 \\
\hline
\end{tabular}

Often what is most revealing in examining such research is what questions was not asked. No questions were asked about the use of cell phones, social network sites (SNS) such as Facebook, podcasts or videos and vodcasts. 
Table 4 summarises Facebook usage and intensity of 572 South African students from 7 universities on a 5 point scale (which ranged from $1=$ strongly disagree to $5=$ strongly agree), unless provided (Johnston, Kawalsky, Lalla \& Tanner, 2011).

\begin{tabular}{|l|l|l|}
\hline \multicolumn{3}{|c|}{ Table 4: Facebook usage and intensity (Johnston, Kawalsky, Lalla \& Tanner, 2011). } \\
\hline INDIVIDUAL ITEMS AND SCALE & MEAN & ST.DEV \\
\hline Facebook Intensity (Cronbach's alpha $=\mathbf{0 . 8 4 0 )}$ & $\mathbf{3 . 0 2}$ & $\mathbf{0 . 9 7}$ \\
\hline $\begin{array}{l}\text { About how many total Facebook friends do you have? } \\
\quad=<10,1=11-50,2=51-100,3=101-150,4=151-200,5=201-250,6=251-\end{array}$ & 3.17 & 2.31 \\
\hline $\begin{array}{l}\text { In the past week, on average, approximately how many minutes per day have you } \\
\text { spent on Facebook? } \\
0=<10,1=10-30,2=31-60,3=1-2 \text { hours, } 4=2-3 \text { hours, } 5=>3 \text { hours }\end{array}$ & 1.69 & 1.44 \\
\hline $\begin{array}{l}\text { Facebook is part of my everyday activity } \\
\text { I am proud to tell people I'm on Facebook }\end{array}$ & 3.03 & 1.31 \\
\hline Facebook has become part of my daily routine & 3.53 & 1.00 \\
\hline I feel out of touch when I haven't logged onto Facebook for a while & 3.07 & 1.27 \\
\hline I feel I am part of the Facebook community & 2.74 & 1.37 \\
\hline I would be sorry if Facebook shut down & 3.36 & 1.08 \\
\hline
\end{tabular}

Table 4 shows that students spent an average of 10-30 minutes a day using Facebook, and had between 100 - 150 friends (Johnston, Kawalsky, Lalla \& Tanner, 2011). Similar studies amongst students in the USA had averages of 10-30 minutes a day, and 150-200 friends. Although the results were not strong on the Likert-scale, the standard deviations were relatively high. Table 4 also shows that Facebook is considered part of student's everyday activity, and a part of their daily routine, which leads to the question, should academics use Facebook to educate? Of the South African students surveyed in 2008, 67\% were Facebook users (Johnston et al., 2011).

Samsodien (2012) asked 298 students how many hours they spend using a phone during a typical weekday during campus hours. As can be seen in Table 5, the majority $(51 \%)$ of students claimed to spend between 1 to 3 hours a day using their phones (Samsodien, 2012). Of the students surveyed, all had a cell phone, while $84 \%$ had a smartphone.

\begin{tabular}{|l|c|c|}
\hline \multicolumn{3}{|c|}{ Table 5: Daily cellphone usage (Samsodien, 2012). } \\
\hline \multicolumn{1}{|c|}{ TIME SPENT } & NUMBER OF RESPONDENTS & PERCENTAGE \\
\hline 0-59mins & 89 & $30 \%$ \\
\hline 1hr-1hr59mins & 83 & $28 \%$ \\
\hline 2hrs-2hrs59mins & 70 & $23 \%$ \\
\hline 3hrs-3hrs99mins & 20 & $7 \%$ \\
\hline 4hrs-4hrs59mins & 13 & $4 \%$ \\
\hline 5hrs-5hrs9mins & 13 & $4 \%$ \\
\hline 6hrs-6hrs59mins & 3 & $1 \%$ \\
\hline 7hrs or more & 7 & $2 \%$ \\
\hline
\end{tabular}


More interesting however were responses to what students were using their phones for while on campus. Students were asked to indicate which activities they used their phones for, based on the following categories:

- $\quad$ Information $=$ News, sport etc.

- $\quad$ Socializing $=$ Chatting, Facebook, instant messaging etc.

- $\quad$ Academic $=$ Reading, studying etc.

- $\quad$ Campus $=$ LMS, vodcasts, resources etc.

- $\quad$ Recreation $=$ Games, music, video etc.

Figure 1 (Samsodien, 2012) shows responses of activity using a phone, but this figure has a major flaw, in that there was no category for zero minutes. So, 30 students might have spent zero minutes a day doing banking, while 6 students might have spent 1-5 minutes a day doing banking, this would result in the $12 \%$ banking activity.

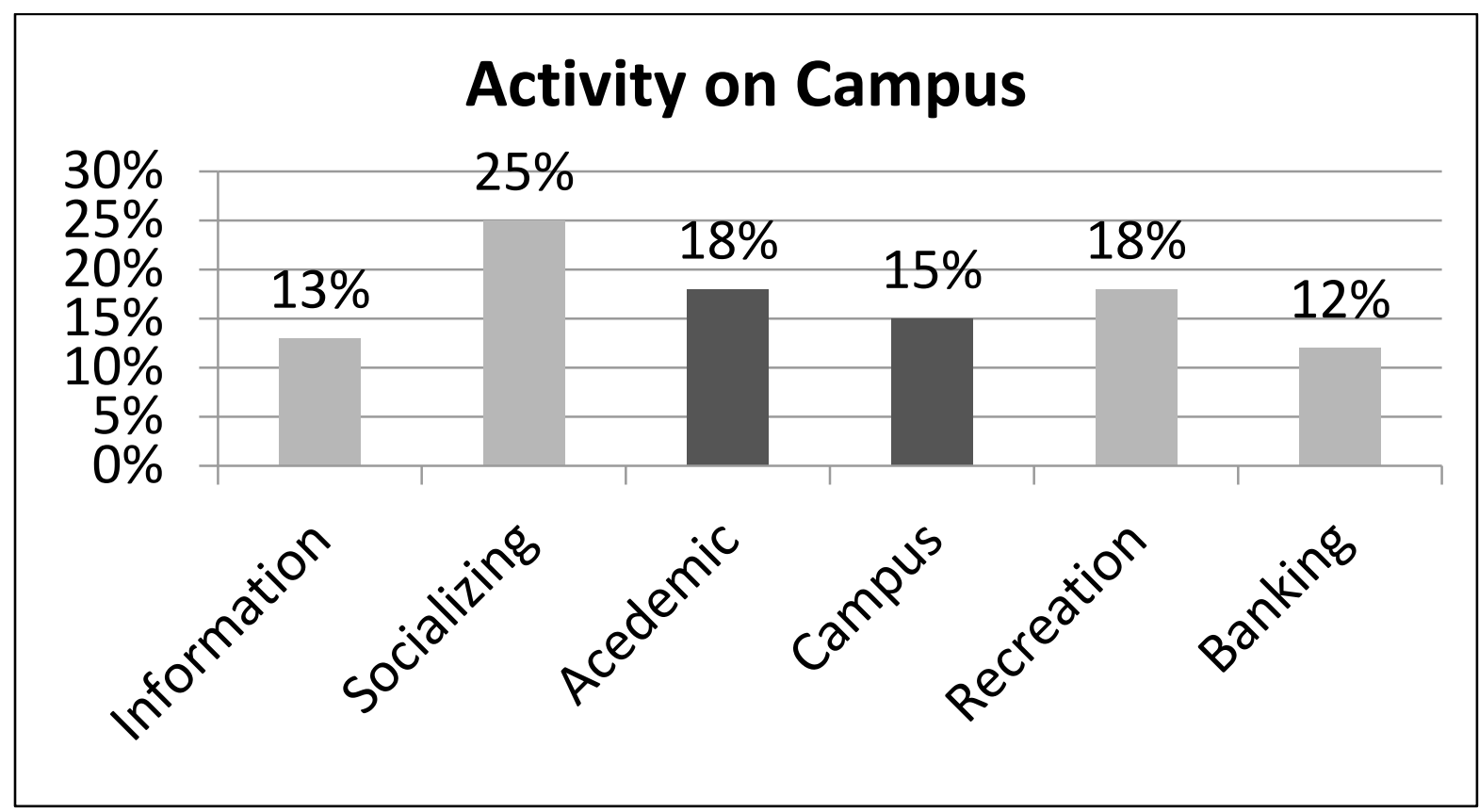

Figure 1: Daily cellphone activity (Samsodien, 2012)

The most interesting statistic is that (flaws not withstanding) 33\% of activity appears to academic and campus related. Students are using their phones while on campus to do educationally related activities.

Visagie and de Villiers (2010) surveyed 86 IS Academics to investigate the reasons why academics in Information Systems and Computer Science departments across five countries, have already or would consider applying Facebook as an academic tool. Visagie and de Villiers (2010, p1) reported that "students change the channels when their needs are not being met." Students desire the establishment of a social foundation with their peers before they are prepared to engage in online group work, and Facebook is an ideal tool to accomplish this. The majority of the academic respondents had personal Facebook accounts. Canadian academics led the way with $75 \%$, while $72.7 \%$ of Australian, and $56 \%$ of South African academics had personal Facebook accounts. Broken down into age categories, $92 \%$ of academics from the Net Generation, $58 \%$ of Generation X, and $46 \%$ of Baby Boomers had personal Facebook accounts. Less than $41 \%$ of the respondents had ever applied any social networking site as a tool for learning, and less than 57\% 
considered using Facebook as an academic tool (Visagie \& de Villiers, 2010). Reasons why respondents would consider using Facebook as an academic tool were grouped into the following themes: "group work and interactivity; student familiarity; sharing and skills; Learning Management Systems (LMS)," while reasons for not considering using Facebook included: "privacy; acceptance; discussions and interactivity" (Visagie \& de Villiers, 2010, p6).

A small study of 15 ICT academics from 5 South African universities on the use of YouTube, found that most used YouTube for social and academic purposes (Roodt, de Villiers, Johnston, Ophoff \& Peier, 2012). Table 6 also shows that $80 \%$ are passive participants on YouTube, and do not post videos onto YouTube. One third said that they made use of YouTube as a teaching tool, but $66 \%$ indicated that an online video platform could be applied in the teaching environment (Roodt, et al., 2012).

Table 6: YouTube as an academic tool for ICT lecturers (Roodt, det al., 2012).

\begin{tabular}{|l|}
\hline QUESTION \\
\hline Do you use YouTube? \\
\hline If you answered "Yes" in Question 1, please answer the fol- \\
lowing: For which purposes do you use YouTube?
\end{tabular}

ANSWERS

93\% said yes, $7 \%$ (1) said no.

$64 \%$ use for both social and academic purposes, $21 \%$ for social reasons, and $14 \%$ only for academic purposes

Are you actively participating in any channels on YouTube, related to your work (teaching) or research interests?

$80 \%$ said No. Sharing is the most commonly performed activity, expect academics to share information/content

Have you ever applied any online video platforms as a tool for academic learning as part of your teaching strategy?

Do you think that an online video platform, such as YouTube, can be applied as a tool for academic learning as part of your teaching strategy?

Would you consider using YouTube as an academic tool where students, and students and lecturers can engage in group work or online discussions related to the subject content?

$33 \%$ said yes, $66 \%$ said no.

$66 \%$ said yes, and $33 \%$ were unsure. No respondents said no.

$27 \%$ said yes, $6 \%$ (1) said no, and $67 \%$ were undecided.

A project in 2009 created podcasts (audio-only files in MP3 format synchronised with PowerPoint) for a class of 411 first year students (Ng'ambi, Lombe, Johnston, \& Kabanda, 2010). The podcasts were posted onto an open source learning management system (LMS), from where students downloaded the podcasts to low-cost ubiquitous playback devices. Many students claimed to have used podcasts in high school, and results showed that $70 \%$ of the students accessed the podcasts at least once, and 28\% accessed them between 5-10 times (Ng'ambi et al., 2010). Students found podcasts useful, and wanted them made available for other courses. Students reported that podcasts enabled them to gain a better understanding of materiel as they reviewed what was said by lecturers at their own pace (Ng'ambi et al., 2010).

\section{Findings}

As a result of research by $\mathrm{Ng}$ 'ambi et al. (2010), vodcasting (an audio-video file synchronised with PowerPoint) was introduced as a learning supplement by the researcher to a first year class of 605 students at the University of Cape Town, South Africa in 2011. Each of 30 lectures was vodcast, and the vodcasts were immediately posted onto an open source learning management system (LMS) for students to access. Academics had no prior experience with vodcasting, and recorded the vodcasts in their offices prior to the lecture using Camtasia, a webcam and Powerpoint. Research results have demonstrated that vodcasts "are an effective and efficient tool for 
enhancing student learning" (Llyod \& Robertson, 2012, p67). At the end of the course, students were asked to rank the benefits of vodcasting, and as can be seen in Table 7, just under $50 \%$ rated the benefits as excellent or good, while $21 \%$ and $15 \%$ rated the benefits as poor or unacceptable in 2011 and 2012 respectively. A weakness in the data in Table 7 is that the term "benefits" was not clearly defined or clarified.

\begin{tabular}{|l|l|l|l|l|l|l|l|}
\hline \multicolumn{7}{|c|}{ Table 7: Benefits obtained from vodcasting. } \\
\hline YEAR & STUDENTS & RESPONSE & EXCELLENT & GOOD & AVERAGE & POOR & UNACCEPTABLE \\
\hline 2011 & 605 & $420(69 \%)$ & $16 \%$ & $30 \%$ & $33 \%$ & $15 \%$ & $6 \%$ \\
\hline 2012 & 665 & $522(78 \%)$ & $18 \%$ & $31 \%$ & $35 \%$ & $8 \%$ & $7 \%$ \\
\hline
\end{tabular}

Many in the Faculty expressed concern that vodcasting would cause lecture attendance to drop, in reality, the opposite occurred and lecture attendance increased by approximately $15-20 \%$. It is unclear why attendance increased, some suggested it was because the vodcasts were so poor, while others (Addo \& Railton, 2008) suggested it was simply because of the need for students to have social interaction. Statistics for the number of downloads (Table 8) shows that the 30 vodcasts were widely downloaded in 2011, and even more so in 2012. The weakness in Table 8s data is that it simply states the number of downloads, and not how many students actually viewed the whole or part of the vodcast, nor what their experiences were.

\begin{tabular}{|l|l|l|l|l|l|l|}
\hline \multicolumn{7}{|c|}{ Table 8: Vodcast downloads } \\
\hline YEAR & STUDENTS & VODCASTS & DOWNLOADS & MAX & MIN & AVE \\
\hline 2011 & 605 & 30 & 41,753 & 301 & 5 & 69 \\
\hline 2012 & 665 & 30 & 112,696 & 958 & 13 & 170 \\
\hline
\end{tabular}

Of the 665 students who responded to the survey in 2012, one did not have a Facebook profile. It was also interesting that no text book was prescribed in the years 2011 and 2012. Additional material in the form of short videos sourced from YouTube were posted on the LMS for each section. Although not downloaded to the same extent as the vodcasts of lectures, they were extensively used.

\section{Recommendations}

One of the modern educational paradoxes, is that students are immersed in ICT in all aspects of their lives except for university (Rosen, 2011). This can cause alienation of students to education, and academics (whatever their generation) must adapt their teaching to meet the needs of the new generations (Net and iGenerations) of students.

This research has shown that Net and iGeneration students have high expectations of academics expertise, and expect academics to use technology both in and outside of the classroom (Oblinger \& Oblinger, 2005). Addo and Railton (2008) showed that students learning preferences included attending interactive classes or demonstrations with face-to-face contact. The majority of students (almost 100\%) and academics had personal Facebook profiles (Visagie \& de Villiers, 2010). All the students surveyed in 2012 had cell phones (84\% had smartphones) which they used for academic purposes (Samsodien, 2012). Although 93\% of academics surveyed used YouTube (Roodt 
at al., 2012), only 33\% had ever applied any online video platforms as academic tools. Students were seen to make extensive use of downloading vodcast lectures.

Academics therefore need to adopt teaching methods which are interactive, social, visual, practical and immediate. Interactive and practical learning is essential in order to stimulate the Net and iGeneration students.

Academics need to make use of presentation software, social networking software, video software (vodcasting), and cell phones both in and out of the classroom. Material needs to be freely and easily available on cellphones and on other platforms such as Facebook, YouTube and LMS's. Communication (listening and answering) with students should be immediate and personal preferably via cellphone, and not broadcast on notice boards or LMSs.

Academics in a Higher Education context should continually ask themselves four questions (Johnston, 2010):

1. Is the content one is teaching relevant?

2. Is one using the most appropriate methods to teach today?

3. Is one doing critical questioning and research?

4. Is one listening and engaging with the students?

Potential areas for further research include delving deeper into the reasons why IS academics are not using cellphones, Facebook, YouTube and other technologies as teaching tools. Focus group discussions and interviews at conferences could be an ideal way to conduct such research. Researchers could examine if the time taken to watch a vodcast is as efficient as reading the material in the same amount of time, and which knowledge areas are best suited to using vodcasts.

\section{References}

Addo, J., \& Railton, M. (2008). Educating my Generation. Unpublished Research as part of an IS Honours degree. University of Cape Town. Cape Town.

Baird, J. (2010). The knowns and the unknowns: Risk-taking, risk management and quality assurance in higher education. Australian Quality Forum (pp. 138-139). Melbourne: Australian Universities Quality Agency.

Barnett, R. (2005). Reshaping the university: New relationships between research, scholarship and teaching. Maidenhead: Open University Press.

Boughey, C. (2009). Inclusion and exclusion in the changing university: A teaching and learning perspective . SANORD Conference. Grahamstown, South Africa.

Brewer, A., \& Walker, I. (2010). Risk management in a university environment. Australian Quality Forum (pp. 19-27). Melbourne: Australian Universities Quality Agency.

Brown, J. S. (2000). Growing up digital. Change, 11-20.

Clayton-Pedersen, A. R., \& O’Neill, N. (2005). Curricula designed to meet 21 st-century expectations. In D. G. Oblinger \& J. L. Oblinger, Educating the net generation (pp. 9.1-9.16). Educause.

Coaldrake, P., \& Stedman, L. (1999). Academic work in the twenty-first century: Changing roles and policies. Occasional Paper Series, Higher Education Division, Department of Education, Training and Youth Affairs, Australia .

Deem, R., Hillyard, S., \& Reed, M. (2007). Knowledge, higher education, and the new managerialism. Oxford: Oxford University Press.

du Toit, A. (2000). From autonomy to accountability: Academic freedom under threat in South Africa. Social Dynamics , 76-133. 


\section{Educating Different Generations}

Frand, J. L. (2000). The information age mindset: Changes in students and implications for higher education. Educause Review, 14-24.

Grummell, B., Devine, D., \& Lynch, K. (2009). The care-less manager: Gender, care and new managerialism in Higher Education. Gender and Education Journal , 21(2), 191-208.

Hartman, J., Moskal, P., \& Dziuban, C. (2005). Preparing the academy of today for the learner of tomorrow. In D. G. Oblinger, \& J. L. Oblinger, Educating the net generation (pp. 6.1-6.15). Educause.

Hauge, Ø., Ayala, C., \& Conradi, R. (2010). Adoption of open source software in software-intensive organizations - A systematic literature review. Information Software Technology, 7(7491), 1-62.

Hayes, R. B., \& Utecht, K. M. (2009). Enterprise resource planning implementation in an institution of higher learning: A case study of Drummond University. Journal of Cases on Information Technology, 42-55.

Howe, N., \& Strauss, W. (2007). The next 20 years: How customer and workplace attitudes will change. Harvard Business Review, 41-52.

Johnston, K. A (2010). What it means to be a teacher in a higher education context today - with emphasis on South Africa. InSite Conference 2010, Cassino, Italy.

Johnston, K. A. , Kawalsky, D., Lalla, N., \& Tanner, M. (2011). Social capital: The benefits of Facebook "friends". Behaviour \& Information Technology, 1-13.

Kapp, K. M.,(2007). Gadgets, games, and gizmos for learning: Tools and techniques for transferring knowhow from boomers to gamers. San Francisco: Wiley.

Lippincott, J. K. (2005). Net generation students and libraries. In D. G. Oblinger, \& J. L. Oblinger, Educating the net generation (pp. 13.1-13.15). Educause.

Lorenzo, G., \& Dziuban, C. 2006. Ensuring the net generation is net savvy. Edited by Diana Oblinger. ELI Paper 2. Retrieved from http://net.educause.edu/ir/library/pdf/ELI3006.pdf

Llyod, S. A., \& Robertson, C. L. (2012). Screencast tutorials enhance student learning of statistics Teaching of Psychology, 39(1), 67-71.

McNeely, B. (2005). Using technology as a learning tool, not just the cool new thing. In D. G. Oblinger, \& J. L. Oblinger, Educating the net generation (pp. 4.1-4.10). Educause. Boulder.

Moratis, L. T., \& van Baalen, P. J. (2002). The radicalization of the multiversity: The case of the networked business school. International Journal of Educational Management, 16(4), 160-168.

Mowles, C., Stacey, R., \& Griffin, D. (2008). What contribution can insights from the complexity sciences make to the theory and practice of development management? Journal of International Development, 804-820.

Ng'ambi D, Lombe A, Johnston K, \& Kabanda S. (2010). Podcasting for mobile learners: Using ubiquitous technologies to enhance learning in large classes. 9th World Conference on Mobile and Contextual Learning. 19-22 October, Valletta, Malta

Ntshoe, I., Higgs, P., Higgs, L. G., \& Wolhute, C. C. (2008). The changing academic profession in higher education and new managerialism and corporatism in South Africa. South African Journal of Higher Education , 22(2), 391-403.

Oblinger, D. G. (2003). Boomers, gen x-ers and millennials: Understanding the new students. Educause Review, 37-47.

Oblinger, D. G., \& Oblinger, J. L. (2005). Educating the net generation. Educause. Boulder.

Ramaley, J., \& Zia, L. (2005). The real versus the possible: Closing the gaps in engagement and learning. In D. G. Oblinger, \& J. L. Oblinger, Educating the net generation (pp. 8.1-8.21). Educause. Boulder.

Rinne, R. (2009). The changing faces of higher education and inclusion and exclusion: Nordic tunes. SANORD Conference. Grahamstown: SANORD. 
Roodt, S., de Villiers, C., Johnston, K., Ophoff, J., \& Peier, D. (2012). YouTube as an academic tool for ICT lecturers. Submitted to the 2013 South African Computer Lecturers Association (SACLA) Conference.

Rosen, L. R (2011). Teaching the iGeneration. Educational Leadership. February, 10-15.

Samsodien Y (2012). Mobile phone usage among first year commerce students at the University of Cape Town. Unpublished Research as part of an IS Honours degree. University of Cape Town.

Saunders, M., Lewis, P., \& Thornhill, A. (2009). Research methods for business students (5th ed.). London: Pearson Education/Prentice Hall.

Visagie, S., \& de Villiers, C. (2010). The consideration of Facebook as an academic tool by ICT lecturers across five countries. South African Computer Lecturers Association (SACLA) Conference, June 2010.

Wager, J. J. (2005). Support services for the net generation. In D. G. Oblinger, \& J. L. Oblinger, Educating the net generation (pp. 10.1-10.18). Educause.

Waldron, K. (2012). The iGeneration: Technology guidelines for parents and teachers. Education Faculty Research. Paper 2. Retrieved from http://digitalcommons.trinity.edu/educ faculty/2

Wallerstein, I. (2004). The uncertainties of knowledge. Philadelphia: Temple University Press.

Walsham, G. (1995). The emergence of interpretivism in IS research. Information Systems Research, 6(4), 376-394.

Windham, C. (2005). The student's perspective. In D. G. Oblinger, \& J. L. Oblinger, Educating the net generation (pp. 5.1-5.16). Educause.

\section{Biography}

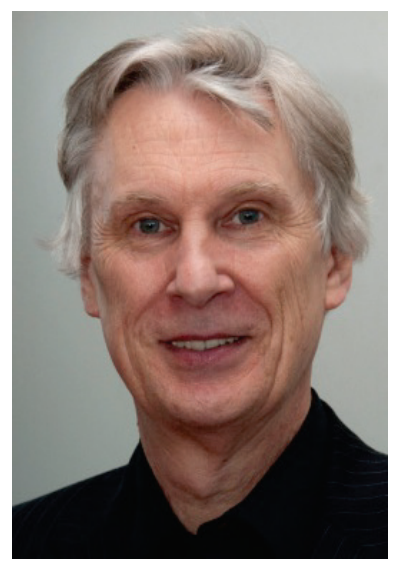

Kevin Johnston is an Associate Professor in the Department of Information Systems at the University of Cape Town. He worked for 24 years for companies such as De Beers, Liberty Life, Legal \& General and BoE. Kevin's main areas of research are ICT Management, Project Management, IS educational issues and Open Source Software. 